Pamiętnik Literacki 2019, 2, s. 71-88

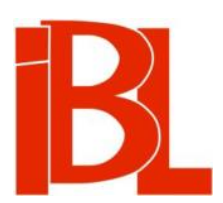

\title{
Wizerunek kobiety w amerykańskiej korespondencji Henryka Sienkiewicza
}

\author{
Aleksandra Chomiuk
}


Pamiętnik Literacki CX, 2019, z. 2, PL ISSN 0031-0514

DOI: $10.18318 / \mathrm{pl} .2019 .2 .4$

ALEKSANDRA CHOMIUK Uniwersytet Marii Curie-Skłodowskiej, Lublin

\section{WIZERUNEK KOBIETY W AMERYKAŃSKIEJ KORESPONDENCJI HENRYKA SIENKIEWICZA*}

Tematem artykułu jest rekonstrukcja Sienkiewiczowskich wyobrażeń o kobietach i kobiecości dokonana na podstawie publicystycznych wypowiedzi autora $z$ czasu amerykańskiej wyprawy z lat 1876-1878. Wybór jako materiału badawczego Listów z podróży do Ameryki wynika z założenia, że to właśnie nowa rzeczywistość, w jakiej znalazł się Sienkiewicz po wyjeździe $z$ kraju, wywołała jego zainteresowanie tą problematyką i uczyniła $z$ niej odrębne zagadnienie, nadając mu wyraźny kształt ideowy. Przedmiot rozważań stanowić będą wypowiedzi dotyczące realnych i postulowanych zachowań kobiet, przypisanych im ról społecznych oraz cech konstytuujących w amerykańskiej korespondencji Litwosa kobiecość jako kategorię społeczno-kulturową. Wykorzystam w pracy również pojęcie stereotypu rozumianego ,jako subiektywnie determinowane wyobrażenie przedmiotu obejmujące zarówno cechy opisowe, jak i wartościujące obraz oraz będące rezultatem interpre-

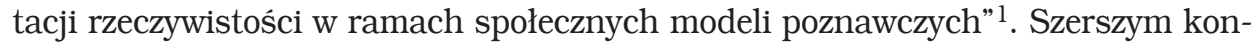
tekstem proponowanego tu sposobu lektury Listów z podróży do Ameryki staną się współczesne ich autorowi dyskursy dotyczące różnic między płciami i kwestii emancypacyjnych.

XIX stulecie to w świecie zachodnim okres istotnych przemian sytuacji kobiet, przekształcania się wielowiekowych wzorców kobiecości. Jednocześnie - jak pisze Anna Żarnowska - ,epoka ta postrzegana jest [...] jako czas zaostrzania norm i rygorów obyczajowych wtłaczających i zamykających kobiety w prywatności”2. Jeśli na początku tego stulecia dominowała w dyskursie publicznym postawa sentymentalno-romantyczna, łącząca idealizację kobiet $z$ koniecznością ich ochrony przed zagrożeniami płynącymi $\mathrm{z}$ amoralnej sfery publicznej, to $\mathrm{w}$ drugiej połowie wieku XIX głosy dezaprobaty wobec emancypacji kobiecej zyskuja już wymiar obsesyjnie mizoginiczny. Dodatkowo ów negatywny wydźwięk jest wzmacniany przez

* Artykuł powstał w ramach projektu badawczego nr DEC-2012/06/A/HS2/00252, zatytułowanego Henryk Sienkiewicz. Obecność w kulturze polskiej XX wieku. Polskość i nowoczesność. Recepcja i nowe odczytania, finansowanego ze środków Narodowego Centrum Nauki.

1 J. B a r t miń s k i, Podstawy lingwistycznych badań nad stereotypem - na przykładzie stereotypu matki. W zb.: Język a kultura. T. 12: Stereotyp jako przedmiot lingwistyki. Teoria, metodologia, analizy empiryczne. Red. J. Anusiewicz, J. Bartmińs ki. Wrocław 1998, s. 64.

2 A. Ża rnow s ka, Czy przełom XIX i XX wieku otwierał kobietom przejścia ze sfery prywatnej do sfery publicznej? Rola barier obyczajowych. „Rocznik Antropologii Historii” 2014, s. 279-280. 
odwołania do pseudonaukowych teorii społecznych, biologicznych i medyczno-psychologicznych ${ }^{3}$. Można by tu powtórzyć za jednym $z$ opracowań poruszanej problematyki:

Im bardziej pozycja mężczyzny stawała się zagrożona, tym oryginalniejsze rodziły się pomysły na przyczyny niższości kobiet, które miałyby raz na zawsze uzasadnić należne im miejsce w społeczeństwie ${ }^{4}$.

Kwintesencję antykobiecego myślenia stanowią poglądy Ottona Weiningera zapisane w książce wydanej na początku kolejnego wieku ${ }^{5}$, określone przez jednego z komentatorów jako „wykład mizoginii na szerokim tle biologii, psychologii i metafizyki”6.

A jednak zmiany emancypacyjne w XIX stuleciu zachodziły. Miał na nie wpływ rozwijający się równolegle wobec przywołanych głosów dyskurs modernizacyjny, inspirowany m.in. przez Johna Stuarta Milla, w Polsce zaś przez Adama Wiślickiego czy Edwarda Prądzyńskiego. Podstawowym impulsem przemian świadomości społecznej były wszakże nie teorie intelektualistów, lecz przekształcenia ekonomiczno-socjalne, przede wszystkim rewolucja przemysłowa, która, zwiększając w Europie Zachodniej zapotrzebowanie na siłę robocza, wyprowadziła kobiety z domów. Podobne procesy, determinowane po powstaniu styczniowym szybkim rozwojem miast i pouwłaszczeniowymi zmianami na wsi, dają się zaobserwować również na ziemiach polskich w rosyjskim zaborze. Zróżnicowanym ideowo forum ujawniającym reakcje na to, co się już dokonało, a także stanowiącym miejsce formułowania kolejnych postulatów związanych $z$ sytuacją i prawami kobiet były w tym okresie czasopisma - jako jedno $\mathrm{z}$ luster odbijających przemiany społeczne oraz medium odgrywające ważną rolę w kształtowaniu postaw Polaków.

Sienkiewicz należał w latach siedemdziesiątych XIX wieku do grona publicystów, dla których istotne były cele propagowane na łamach „młodej” prasy warszawskiej. $Z$ pewnością też jego coraz bardziej rozpoznawalny głos miał wpływ na kształt owej debaty. Nadmieńmy tu jednak, że w tym czasie samo zbliżenie ideowe pisarza do obozu „młodych” nie oznaczało jego automatycznej akceptacji wszystkich postulatów łączonych z owym nurtem. Również amerykańska podróż, która - jak podkreślano - zradykalizowała poglądy Sienkiewicza „do tego stopnia, że nie mieściły się one w granicach "umiarkowanego postępu" polskich pozytywistów"7, akurat w odniesieniu do kwestii kobiecej raczej uświadomiła mu kierunek zmian, który nie zyskał aprobaty artysty. Jeśli też w felietonach publikowanych na łamach „Niwy” i „Gazety Polskiej” społeczno-obyczajowy wymiar sytuacji kobiet nie stano-

Zob. M. D o r a, Ułomność (z) natury. Kobieta w dyskursie naukowym XIX wieku. „Zeszyty Naukowe Towarzystwa Doktorantów UJ. Nauki Społeczne” 2012, nr 2.

4 Ibidem, s. 124.

5 Chodzi tu o książkę Geschlecht und Charakter. Eine prinzipielle Untersuchung opublikowaną w roku 1903 w Wiedniu i Lipsku. Polski przekład: Płeć i charakter, ukazał się w roku 1911 w tłumaczeniu O. Ortwina.

6 L. So kó1, Metafizyka płci: Strinberg, Weininger $i$ Witkacy. „Pamiętnik Literacki” 1985, z. 4, s. 5.

7 T. B u j n i c k i, Pozytywista Sienkiewicz. Linie rozwojowe pisarstwa autora „Rodziny Połanieckich”. Kraków 2007, s. 35. Na temat związków pisarza z ideami pozytywizmu zob. T. Bujnicki, Sienkiewicz $w$ „pozytywistycznym słoneczniku”. W zb.: Pozytywiści warszawscy „Przeglad Tygodniowy” 1866-1876. Seria 1: Studia, rewizje, konteksty. Red. nauk., wstęp A. J a nick a. Białystok 2015. 
wi właściwie przedmiotu samodzielnych rozważań, to w Listach zyskuje on pełniejszą bezpośredniość, najpierw w części londyńskiej, następnie w korespondencji odnoszącej się do Stanów Zjednoczonych. Wtedy także w stopniu znacznie większym niż we wcześniejszej felietonistyce zaczynaja pojawiać się uogólnione, różnorako wartościowane wizerunki kobiet. Notatki inspirowane pobytem w Anglii da się w kontekście tej tematyki streścić dwoma hasłami. Pierwsze, sformułowane przez samego Litwosa, brzmi: „Kobieta nie ma tu żadnych praw, a korzysta ze wszystkich [...]" (S 31) ${ }^{8}$. Drugie natomiast mogłoby przybrać kształt następujący: nie istnieje taka nędza i upadek moralny, $\mathrm{z}$ których, dzięki chęci poprawy oraz wsparciu ludzi dobrej woli, nie byłaby ona w stanie się wydobyć.

Zdanie sformułowane przez Sienkiewicza dotyczy praw i wolności płci „słabszej” w tym kraju. Punktem wyjścia owej refleksji staje się opis urody przechadzających się po Londynie Angielek, co następnie prowadzi autora ku rozważaniom na temat angielskich zwyczajów i praw. Otrzymujemy tu wizerunek wyestetyzowany, odległy od jakichkolwiek nawiązań do sfery biologii i seksualności, odwołujący się do bogatego słownictwa wartościującego (,piękne”, „regularne”, „idealne”, „wykwintne”, „ogładzone”, „dobre”, S 36). Jednocześnie jest to obraz odindywidualizowany, nie odnosi się do konkretnych osób, lecz do zbiorowości. Charakterystyczne dla niego wydaje się również autorskie zdystansowanie emocjonalne. Ów dystans można tłumaczyć wpisana w tekst „anielskością" statusu przedstawianych kobiet, upodobnionych do niebianek, które "tylko chwilowo zstapiły na ziemię, aby poigrać wśród zieloności [...]” (S 36). Potwierdzeniem wrażenia ich „nieziemskości” jako postaci rodem bardziej z literatury czy malarstwa niż z życia stają się kolejne wypowiedzi: „Twarze niektórych - to prawdziwe pomysły poetyczne [...]”, ,podobnie idealne widziałem tylko w rysunkach Grottgera”, „Zdaje się, że te pieszczone dziewczyny arystokratyczne nie $z$ krwi i ciała się składaja, ale $z$ mieszaniny promieni słonecznych, mgły, blasków jutrzenki i duszy" (S 36). W ostatnim fragmencie mamy do czynienia Z impresjonistycznym prześwietleniem owego wizerunku, co dodatkowo wzmacnia jego wymiar estetyczny. W polemice więc $z$ twierdzeniem Wojciecha Tomasika, który łączy te doznania XIX-wiecznego publicysty z modernizującą się miejskością, chcę podkreślić, że Sienkiewiczowska „poetyczność” nie niesie tu ze sobą skojarzeń z rytmem życia mieszkanek nowoczesnej metropolii. To rodzaj odbioru kobiecej urody bliższy kontemplacji dzieła sztuki niż - jak chciał Tomasik - opisom atmosfery wielkich magazynów mody czy wystaw sklepowych ${ }^{9}$. Nie wydaje się też, ażeby intencją Litwosa stało się, w odniesieniu do kobiet z Hyde Parku, eksponowanie doznań „Z natury takich, jakie wynieść mógł klient eleganckich domów publicznych” ${ }^{10}$. Sposób przedstawienia kobiecej urody odległy jest od skojarzeń erotycznych, o czym świadczy zarówno sam dobór słów, jak i zastosowany typ metaforyki. Wystarczy zreszta zestawić ten opis z fragmentem o 2 lata późniejszego paryskiego sprawozdania Litwosa, by dostrzec jego odmienność od wizerunków mieszkanek stolicy Francji, nasyconych atmosferą zmysłowości i rozwiązłości:

8 Skrótem S odsyłam do: H. Si enkiewicz, Listy z podróży do Ameryki. T. 1. W: Dzieła. T. 41. Red. J. Kr zy ża n ow ski. Warszawa 1950. Liczby po skrócie oznaczają stronice.

9 W. To m a si k, Ikona nowoczesności. Kolej w literaturze polskiej. Wrocław 2007, s. 56.

10 Ibidem. 
ogrody brzmią muzyką; na bulwarach tłumy świetne, modne i pyszne; damy kameliowe - prawdziwe komety błędne o jasnych warkoczach, z oczami jak gwiazdy. A potem wszystko, jeśli chcecie: słychać szelest jedwabiów, powietrze pełne zapachów, upajające, twarze śliczne i młode. Omdlałe spojrzenia, rozchylone usta, szepty, gorące oddechy, bicia podnieconych pulsów - upojenie, szał ${ }^{11}$.

Co jednak również istotne, wbrew pozytywnym konotacjom słów tworzących londyński opis, nie jest on do końca aprobatywny. Przy całej akceptacji dla angielskiego porządku społecznego i miejsca w nim kobiet publicysta dostrzega wszakże sztuczność egzystencji przedstawicielek wyższych sfer, ujmując ją w następujących metaforycznych sformułowaniach:

Nigdy troska powszednia, nigdy znój, nigdy zwykła ziemska niedola nie zachmurzyły żadnej z tych jasnych twarzy. Praca dla nich ma znaczenie zabawy; otacza je przepych, życie wykwintne, ogładzone, wysokie, jak gdyby zawsze świąteczne. [...] Są to kwiaty rodzaju ludzkiego: kwitną - oto wszystko. To ich cel - i zasługa aż do chwili zamążpójścia. Potem wydają na świat dzieci, co jest także zasługą, i w ogóle, jak mówią ludzie znający angielskie społeczeństwo, są dobrymi żonami i matkami, co jeszcze jest zasługą; potem umierają i oczywiście idą do nieba, co już nie jest zasługą, ale nagrodą - i co im łatwiej przychodzi, bo w życiu prawie nie znały pokus i złego. [S 36]

Idealizacja prowadzi więc w końcu do zawoalowanej krytyki wynikającej z poczucia „odświętności” egzystencji owych „dziewczyn arystokratycznych”, obarczonych - po mickiewiczowsku rozumiana - wina kogoś, „Kto nie doznał goryczy ni razu $[\ldots . .] "$.12 .

Z upoetyzowanym wizerunkiem londynek zostaje zestawiony „piekielny” obraz młodego nędzarza zarabiającego na życie sklejaniem pudełek, dla którego prezentacji uruchomiono negatywne leksykę i frazeologię:

obywatel ten ma lat szesnaście, dziury na łokciach, czoło idioty, spróchniałe zęby i wystrzępione majtki. Ma także jakiś surdut jakiegoś koloru, ale nie ma za to koszuli. [...]

[...] Chłopak nie umie czytać i pisać, klnie za to nadzwyczaj wprawnie. Widać także, że trochę i pije, bo jak zimno, to dżin rozgrzewa. [S 37]

O owej postaci również, choć w innym sensie, można powiedzieć, że jest „zrobiona” $z$ literatury. Tym razem jednak stereotyp zostaje przejęty nie $z$ jej kart romantyczno-romansowych, lecz $z$ najbardziej ciemnych stron powieści Charlesa Dickensa ukazującego bohaterów zmuszonych - dla utrzymania się przy życiu - do pracy po kilkanaście godzin dziennie lub do kradzieży. Dopowiedzmy tu, iż skutkiem zestawienia obu opisów stało się także skontrastowanie zagwarantowanych prawem Habeas Corpus Act - ale, jak podkreśla Sienkiewicz, tylko teoretycznych - swobód młodocianego obywatela imperium brytyjskiego $\mathrm{z}$ wolnością kobiet spotkanych w tym samym parku, które, przypomnijmy: „nie mają tu żadnych praw, a korzystaja ze wszystkich [...]". O jakich to jednak realnych prawach pisze Litwos? Zacytujmy kolejny fragment Listów, żeby dostrzec ograniczony zakres owej wolności kobiecej, polegającej jedynie na możliwości poruszania się bez asysty samozwańczych „opiekunów”:

Żaden Don Juan nie zbliża się tu do idącej samotnie dziewczyny i nie mówi jej, jak się to prakty-

11 H. Si enki ew ic z, Listy z podróży i wycieczek. W: Dzieła, t. 44, s. 49-50.

12 A. Mickiewicz, Dziady. Część II. W: Dzieła. Wyd. Jubileuszowe. T. 3: Utwory dramatyczne. Warszawa 1955, s. 17. 
kuje w pewnym znanym mi mieście: „Jak to, pani - tak piękna, tak młoda i sama? Dzień dobry, aniołku!" Pierwszy lepszy dżentelmen spotkawszy takiego Don Juana w roli czynnej, wbiłby mu kapelusz na głowę aż po szyję, połamałby żebra, popodbijał starannie oczy i następnie oddał w ręce policemana. Kobieta zaczepiona nie potrzebuje tu zresztą innej obrony prócz policjanta. Spokojny ten człowiek dotyka wówczas złowrogą laseczką ramienia awanturnika i w imieniu Jej Królewskiej Mości wiedzie go do kozy, sąd zaś za jedno nic, za jeden mały komplemencik, bardzo wreszcie uprzejmy, skazuje go czasem i na pół roku więzienia. [S 40]

Warto także przy okazji spytać, czy ostrze ironii zostaje tu skierowane jedynie przeciw zaczepiającym kobiety „Don Juanom”, czy też może w podtekście wypowiedzi pojawia się sugestia związana $z$ niewspółmiernością winy wobec kary. To wrażenie niejednoznaczności ocen postępków męskich w stosunku do kobiet podsyca inna przedstawiona $\mathrm{w}$ Listach informacja, tym razem dotyczaca wprowadzonego w Kalifornii prawa przeciwdziałającego przemocy domowej. Przywołajmy ją tu, burząc nieco chronologię podróży Sienkiewicza:

W Kalifornii zapadło niedawno postanowienie, że mąż, który by bił swą żonę, otrzyma dwadzieścia jeden bizunów ze skóry bawolej. Dlaczego dwadzieścia jeden, nie dwadzieścia lub dwadzieścia pięć? - są to tajemnice amerykańskiej legislatury. Koniec końcem, kto się nie uwinął zawczasu, temu teraz zamknięta droga na wieki. [S 105]

Tu już trudno mieć wątpliwości co do kierunku krytyki. Pomijając samo ośmieszające przedstawienie całej sprawy ${ }^{13}$, której istotą staje się nie tyle bicie żony, ile liczba karnych bizunów, odnajdujemy też bezpośrednie dopowiedzenie:

Gdyby istotnie surowość mężów przechodziła tu granice i gdyby prawo takie zapadło wskutek istotnych nadużyć, można by je jeszcze wyrozumieć; ale w kraju, gdzie mąż pracuje jak cztery konie, żona zaś kołysze się również cały dzień w biegunowym krześle, po powrocie zaś małżonka przyprawia go z takim sosem, z jakim jej się podoba, jest to tylko dolewanie oliwy do ognia. Rozsądni ludzie śmieją się tedy z tego niewczesnego wyskoku filantropii [...]. [S 105]

Wracając jednak do opisanych przez Litwosa bogatych Angielek, chronionych jak to postrzega publicysta - zarówno przez obyczaj, jak i praktykę sądowniczą: za właściwą opozycję dla nich można uznać dopiero dziewczynę z „Żółtego domu” ( $\mathrm{S}$ 43). Z pewnością bowiem w realnym świecie nie wstawi się za nią ani żaden (a tym bardziej „pierwszy lepszy”) dżentelmen gotowy do obrony samotnej kobiety przed zaczepkami „Don Juanów”, ani też sąd skupiony w tym czasie - w znacznie wyższym stopniu niż na pomocy kobietom wykorzystywanym seksualnie - na wspieraniu regulacyjnych działań władz wobec zjawiska prostytucji ${ }^{14}$.

Tego rodzaju zabiegi językowe, wyprowadzające problem ze sfery poważnego dyskursu społecznego, zostały określone mianem „strategii trywializacji”. Zob. N. Krzy ż a n o w s k a, Kobiety w (polskiej) sferze publicznej. Torun 2012, s. 283-284.

14 Trzeba pamiętać, iż w czasie, gdy Sienkiewicz przebywał w Londynie, zjawisko prostytucji w Anglii i w Irlandii zostało uregulowane uchwalonymi przez parlament angielski w latach 1864-1869 ustawami o zwalczaniu chorób zakaźnych (Contagious Diseases Acts), uprawniającymi władze państwowe do identyfikacji i kontroli każdej kobiety, którą podejrzewano o nierząd, oraz do narzucenia obowiązkowego badania jej pod kątem chorób wenerycznych. W wypadku ich stwierdzenia można było zatrzymać kobiety w szpitalach zamkniętych, w razie zaś odmowy poddania się badaniom - zamknąc w więzieniu. Oznaczało to odmienne traktowanie kobiet, których aktywność seksualna była rejestrowana i kryminalizowana, oraz mężczyzn - wolnych od odpowiedzialności za korzystanie $z$ ich usług. Prawo to - początkowo obowiazujące jedynie w kilku miastach porto- 
Przyjrzyjmy się więc sposobowi ujęcia tego problemu społecznego, wpisanego w korespondencji Sienkiewicza w londyńskie antynomie: piękna i brzydoty, podniosłości i przyziemności, dobra i zła, cnoty i grzechu, bogactwa i nędzy ${ }^{15}$. Należy podkreślić, że język użyty we wspominanym fragmencie Listów jest znacznie mniej represywny niż ten, który pojawia się chociażby w ówczesnych słownikach języka polskiego $^{16}$. Litwos nie tylko odwołuje się do tradycyjnych - w literackich opisach prostytutek - leksyki i frazeologii o charakterze religijno-moralistycznym („dziewczęta [...] upadłe”, „otchłań występku”, „droga cnoty”, „sumienie”, „życie czyste”, „sromota”, S 42-43), ale nawet cytuje fragment Ewangelii św. Łukasza oddajacy radość z poprawy grzesznicy (zob. S 43). Publicysta, wprowadzając też pewien zasób informacji o wizualnych znakach wcześniejszej hańby Jenny (wyrażenia takie jak: „jaskrawa suknia”, „uczernione brwi”, „sztuczne rumieńce na twarzy” 〈S 44〉, kreuja stereotypowy wygląd przedstawicielki tej profesji), objawia tak radykalna przemianę dziewczyny, że aż pozwalająca jej na zmianę tożsamości: „W skromnej sukni, z gładko przyczesanymi włosami, nie poznaje sama siebie” (S 44).

To spojrzenie na kwestię prostytucji, wraz z językiem służącym jej opisowi, możemy, oczywiście, uznać za rażące naiwnością i sentymentalizmem nie tylko na tle obecnej wiedzy na temat mechanizmów tego zjawiska ${ }^{17}$, ale nawet w porównaniu z niektórymi wypowiedziami $z$ epoki, przenoszacymi je ze sfery moralności indywidualnej do sfery patologii społecznych. Rzeczywiście, brak u Litwosa prawnej, ekonomicznej czy medycznej terminologii umożliwiającej pogłębioną refleksję nad przyczynami i konsekwencjami prostytucji bądź też np. nad stosunkiem państwa i społeczeństwa do płatnego seksu. Dodajmy jednak, że nie ma tu również - ude-

wych i garnizonowych, po paru latach rozszerzone na wszystkie ośrodki, gdzie stacjonowało wojsko - wzbudziło ogromne kontrowersje. Ustawę uznano za naruszająca podstawowe prawa człowieka. Walczyło z nią m.in. Narodowe Stowarzyszenie Kobiet na rzecz Uchylenia Ustaw o Chorobach Zakaźnych z J. Butler na czele. Rezultatem kampanii przeciw ustawie stało się zebranie ponad dwu i pół miliona podpisów, co poskutkowało jej uchyleniem w roku 1886 (zob. P. B a rtley, Prostitution: Prevention and Reform in England, 1860-1914. London - New York 2000. - Ph. H o we 11, Prostitution and Racialised Sexuality: the Regulation of Prostitution in Britain and the British Empire before the Contagious Diseases Acts. „Environment and Planning D: Society and Space" 2000, z. 3).

O antynomiach obrazu Londynu w Listach z podróży do Ameryki pisał To m a s i k (op. cit., s. 45).

Warto zauważyć, że w dwu XIX-wiecznych słownikach: w Stownikujęzyka polskiego M. S. B. Li nd e g o i w Słowniku Wileńskim, nie odnajdujemy - stosunkowo najsłabiej nacechowanego - słowa „prostytutka”, mamy w nich zaś hasła: Kurwa, Nierzadnica oraz Wszetecznica; w drugim z kompendiów pojawia się natomiast słowo „prostytucja”, wyjaśnione jako 'nierząd, rozpusta' (Słownik języka polskiego [...] do podręcznego użytku. Wypracowany przez A. Z d a now i c za [i in.]. Wyd. M. Orgelbrand. Cz. 2. Wilno 1861, s. 152. Na stronie: https://eswil.ijp.pan.pl/?str=otworz-slownik (data dostępu: 2 IV 2019)). Nawet jednak w XX-wiecznym Słowniku Warszawskim, do którego ten leksem zostaje już wprowadzony, jego synonimami nadal pozostają określenia piętnujące i stygmatyzujące kobietę, takie jak: „nierządnica”, „wszetecznica”, „kurwa” oraz „ladacznica” (Stownikjęzyka polskiego. T. 4. Red. J. Karłowicz, A. Kryński, W. Nie dźwiedzki. Warszawa 1908, s. 1027. Na stronie: http://ebuw.uw.edu.pl/dlibra/docmetadata?id=237\&from=publication 〈data dostępu: 2 IV 2019〉).

17 Zob. L. Bernstein, Sonia's Daughters: Prostitutes and Their Regulation in Imperial Russia. Berkeley 1995. - Bartley, op. cit. - J. Sikorska-Kulesza, Zto tolerowane. Prostytucja w Królestwie Polskim w XIX wieku. Warszawa 2004. 
rzających w wielu tekstach prasowych - sformułowań żartobliwych czy wręcz ujawniających lekceważący stosunek do nierządnych „córek Ewy” ${ }^{18}$, które to określenia należałoby uznać za sposób pomniejszania i bagatelizowania zjawiska. Najwięcej miejsca zajmuje natomiast „ckliwy” (jak to wyraził Zdzisław Najder) opis wyidealizowanych działań opiekuńczych i wychowawczych wobec „kobiet upadłych”19. Analizując stylistyczne uchwycenie tego obrazu i dostrzegając zastosowana przez Litwosa obyczajową autocenzurę, winniśmy też uwzględnić przyjętą w wypowiedzi stylistyczno-gatunkową konwencje przedstawiania rzeczywistości i związane z owym przedstawianiem decorum ${ }^{20}$. Najprawdopodobniej Sienkiewicz po prostu uznał, że problem prostytucji - jako temat felietonowo-sprawozdawczej pogawędki - byłby znacznie trudniejszy do zaakceptowania przez szerokiego odbiorcę popularnych gazetowych odcinków w języku innym niż sentymentalno-moralistyczny ${ }^{21}$. W ten sposób zostaje wystylizowana scena przyjęcia bohaterki do przytułku, wprowadzająca również symboliczny motyw ręki wyciągniętej do upadłej kobiety przez ludzi dobrej woli:

Wśród ciemnej, zimnej i dżdżystej nocy wychudzona ręka targa gorączkowo za dzwonek w bramie „Żółtego domu”. Zza bramy nie odpowiada groźne warczenie psa ani gniewliwe: „Kto tam?” stróża nocnego. Drzwi otwierają się cicho, widać ciemny korytarz, jakaś ciepła, łagodna dłoń bierze zziębniętą rękę nieszczęśliwej i prowadzi ją za sobą. [S 43]

To konwencjonalne obrazowanie, upodobnione do wielu literackich ujęć tego okresu, doskonale wpisuje się więc w oczekiwania czytelnicze ${ }^{22}$. Istotna jednak konsekwencją takiego sposobu przedstawienia prostytucji jest - poza oczywistym spłyceniem problemu - jej uzależnianie od konkretnych kobiecych wyborów, a zatem postrzeganie zjawiska bardziej jako zła indywidualnego niż społecznego ${ }^{23}$.

Sikorska-Kulesza, op. cit., s. 305.

Z. N a j d e r, O „Listach z podróż do Ameryki” Henryka Sienkiewicza. „Pamiętnik Literacki” 1955, z. 1, s. 88. Zob. też na temat tego fragmentu Listów: B. O b s ul ew i c z-Ni e w iń s ka, „Nieobałamucona" wrażliwość. Pisarze okresu pozytywizmu o filantropii i miłosierdziu. Lublin 2008, s. 269-270.

Bardziej przenikliwa, jeśli chodzi o ujawnianie mechanizmów zjawisk społecznych, jest część Listów dotycząca Nowego Świata, na czym mógł zaważyć wpływ dzieła A. de To c qu eville e'a O demokracji $w$ Ameryce (Przeł. B. J a ni cka, M. Król. Warszawa 2005). W amerykańskich relacjach Litwosa wszakże o prostytucji w ogóle nie ma mowy. W kontekście pobytu w Stanach warto jednak wziąc pod uwagę również prywatne listy Sienkiewicza do J. Horaina i D. Zglińskiego, w których dzieli się on swoimi najbardziej osobistymi obserwacjami także i w odniesieniu do tego zjawiska.

W pracy S. Mile w s ki e g o Ciemne sprawy dawnych warszawiaków (Warszawa 1982) znajdujemy informację, że jeszcze w końcu XIX wieku podejmowanie problematyki związanej z mechanizmami prostytucji czy też przywoływanie jakichś nazbyt szczegółowych omówień tego zjawiska w czasopismach kierowanych do ogółu czytelników było postrzegane jako niestosowne ze względu na poczucie, iż „szerzy się w ten sposób demoralizacje” (ibidem, s. 90).

Dowodem na popularność takich ujęć jest choćby powodzenie granej w Warszawie kilka lat wcześniej sztuki A. Dumasa Pojęcia pani Aubray, wzbudzającej nb. też obawy o zbytnią pobłażliwość publiczności teatralnej dla „kobiet skalanych przez długie lata”, „istot walających się w błocie [...]”, których „w żadnym jednak razie nie wolno [...] idealizować lub stawiać bohaterskich ołtarzy” (E. L. [E. Lubaws ki], „Pojęcia pani Aubray. Komedia w IV aktach” Alexandra Dumasa syna. Przeł. W. U mi a s t ow ski. „Biblioteka Warszawska” 1868, t. 3, s. 506).

Następująco o literackich obrazach prostytucji w twórczości tego okresu pisze E. I h n a towicz (Miasto kryminalne? W zb.: Miasto, kultura, literatura. Wiek XIX. Materiaty sesji naukowej. Red. 
Próba zasygnalizowania powodów czyniących z kobiety ofiarę sytuacji społeczno-ekonomicznej dokonuje się w ogólnikowym, poddanym eufemizacji, trybie metaforycznym, który „prywatyzuje” jej problemy:

Czasem znów zdarza się, że dziewczyna jeszcze cnotliwa opiera się i woła ratunku, żeby nie wpaść w otchłań występku, ale głód ciagnnie ją za jedną rękę, chłód za drugą, przemoc socjalna popycha ją $\mathrm{z}$ tyłu [...]. [S 43] $]^{24}$

Warto wszakże podkreślić, choć może to bardziej skutek oddziaływania schematów literackich niż samoistna zasługa Litwosa ${ }^{25}$, że nie tylko nie deprecjonuje on swojej bohaterki, lecz i daje jej szanse poprawy, czyniąc to zresztą w duchu haseł użyteczności publicznej: „Najlepsze robotnice, najlepsze służące wychodzą $z$ tego domu. Młodsze często potem wychodzą za mąż, są dobrymi żonami i matkami” (S 45).

Ten pozytywistyczny utylitaryzm, pozwalający wierzyć w skuteczność działań instytucji walczących z nierządem, różni opowieść o Jenny od tekstów wielu autorów tego czasu, nawet współtworzących dyskurs emancypacyjny, którzy nie zdołali uwolnić się od sprzeczności między hasłami dowartościowującymi kobietę a stereotypowymi diagnozami jej słabości moralnej. Przykładem może być opublikowana w „Przeglądzie Tygodniowym” wypowiedź zwolennika kobiecej edukacji zawodowej, piętnującego kobietę niewykształconą, która:

nic nie umiejąc, albo krzątając się tylko koło domu, jest [...] tylko materialnym uszczerbkiem dla męża lub, gdy nie ma dzieci, $\mathrm{z}$ braku zajęcia w nieobecności pracującego $\mathrm{w}$ warsztacie małżonka, puszcza się na wszelkie zboczenia moralne ${ }^{26}$.

Zarówno bowiem rozpoznajemy tu - podobny do Sienkiewiczowskiego - kontekst moralistyczny, jak i dodatkowo odnajdujemy kuriozalną motywację kształcenia kobiet, wynikająca z założenia o ich „przyrodzonej” skłonności do grzechu w sytuacji, gdy nie mają nic do roboty ${ }^{27}$.

Należy też podkreślić, że publicysta ujawnia troskę o dobro opisywanej bohaterki, nie zaś jedynie o utrzymanie jej pod policyjno-medyczną kontrolą, co stanowiło podstawowy postulat zawarty w większości profesjonalnych wypowiedzi tego czasu na temat prostytucji. Przykładem takiego „regulacyjnego” podejścia

J. D a ta. Gdańsk 1993, s. 114-116): „Pozytywiści zatrzymali się przed odtworzeniem mechanizmu społecznego, poprzestając na opisie okoliczności oraz charakterów i mechanizmów psychicznych jednostek".

24 W podobny sposób sygnalizował wcześniej Litwos powody negatywnych wyborów moralnych chłopca z Hyde Parku: „Tymczasem nędza mówi do niego: "Zabij!«, głód: "Ukradnij!«, chłód: „Upij się!» Oto jego nauczyciele: innych nie ma” (S 38).

25 Zob. Ihn atowicz, op. cit., s. 118.

26 Cyt. za: A. Kow a l z z k ow a, Młodzi pozytywni-przecieranie dróg ku polskiej przyszłości. W zb.: Pozytywiści warszawscy, s. 46.

27 Oczywiście, tego negatywnego osądu natury kobiecej i tak w niczym nie da się porównać do zapisów podsumowujących „badania” włoskiego XIX-wiecznego kryminologa C. Lombrosa, który nie dość, że usprawiedliwiał samą prostytucję jako „rzemiosło [...] nie [...] bez pewnego pożytku społecznego”, stanowiące „upust dla zmysłowości mężczyzn, i co za tym idzie, zapobiegające wielu zbrodniom [...]”, potępiając jednocześnie bezapelacyjnie same trudniące się tym „rzemiosłem” kobiety, to jeszcze wyróżnił wśród nich te, które nazwał - ze względu na określone cechy psychofizyczne - „prostytutkami urodzonymi” (C. Lo m b r o s o, G. F e r r e r o, Kobieta jako zbrodniarka i prostytutka. Studia antropologiczne poprzedzone biologia i psychologia kobiety normalnej. Przeł. J. Szen hak. Warszawa 1895, s. 485). 
do nierzadu jest np. praca Jana Maurycego Kamińskiego O prostytucji (wyd. 1: $1869)^{28}$ - jej autor, prawnik $\mathrm{Z}$ wykształcenia, odsłaniając społeczne i ekonomiczne uwarunkowania zjawiska, a także wiele miejsca poświęcając refleksji nad sposobami pomocy kobietom, przyznaje się jednocześnie do „pewnej sympatii dla projektu zdającego się zaradzać wielu niedogodnościom [...]”, polegającego na uczynieniu „domów publicznych [...] zakładami państwowymi, utrzymywanymi kosztami skarbowymi [...]”, których „administracja [...] złożona [być miała] w ręku nominowanych przez władzę urzędników"29.

Jak zostało to zasygnalizowane, londyńska moralistyka społeczna Litwosa jest mocno podszyta inspiracjami literackimi. Na rolę odniesien dickensowskich w opowieści o „Źółtym domu” zwrócił uwagę Wojciech Tomasik, wskazujący, że Sienkiewicz nie tylko odwoływał się do literackich fabuł Dickensa o „kobietach wracających po upadku na drogę cnoty"30, ale i prawdopodobnie wzorował zasady ich resocjalizacji na sposobie działania konkretnej londyńskiej instytucji, „której powstaniu i działalności autor Samotni asystował [...]"31. Rzecz jasna, trudno powiedzieć, czy Litwos faktycznie wiedział o londyńskim domu Urania Cottage, gdzie wychowywano zbłąkane dziewczęta ${ }^{32}$. Cytowany Kamiński przywołał inną instytucję, której reguły również w jakimś stopniu mogły zainspirować autora Listów: „dom [...] założony w r. 1854 w Paryżu przez pannę Chupin pod nazwą Przytułku Ś-tej Anny”33, opisany jako miejsce, „gdzie potrzebujesz tylko zastukać, aby ci otworzono, tak jak ci obiecała Ewangelia, [...] gdzie potrzebuja tylko żalu i odrazy do przeszłości, z którą w jednej chwili możesz się rozłączyć. Tam nie żądają od ciebie ani pokuty, ani biczowania, ani włosienicy, ani umartwień, ani nawet obłudy"34.

Podobnie brzmią słowa dotyczące mieszkanek „Żółtego domu”:

Nie każą tu im pokutować za przeszłość, ale każą o niej zapomnieć. Otaczają je atmosferą czystą: pracy, pogody, spokoju i niewinności, a atmosfera ta obejmuje je i przesiąka w najbardziej zepsute serca. [S 45]

Nazwisko M. Kamińskiego jako kompetentnego i wszechstronnego autora współpracującego z „Kurierem Codziennym" pojawia się w jednym z felietonów H. Sienkiewi c za (Sprawy bieżące. W: Dzieła. T. 47, s. 40), co świadczyłoby o orientowaniu się publicysty w podejmowanych przez warszawskiego prawnika zagadnieniach społecznych.

J. M. Ka mińs ki, O prostytucji. Wyd. 2, znacznie powiększ. Warszawa 1875, s. 188, 186. Dopowiedzmy, że ów projekt zostaje przywołany nie bez pewnych zastrzeżeń. Maja one jednak charakter głównie organizacyjny. Autor zadaje bowiem pytanie o sposób naboru „pracownic” do owych, dbających o „dobro publiczne”, państwowych instytucji, wskazując, iż przy całej niewłaściwości wchodzenia w jakiekolwiek umowy ze stręczycielami, sama „liczba [kobiet] złapanych na pokątnym nierządzie nie wystarczyłaby na miejscowe zapotrzebowanie i skutkiem tego tenże nierząd pokątny miałby zawsze zapewniony stały pokup" (ibidem, s. 187-188).

Toma sik, op. cit., s. 52. Na temat dickensowskich tropów Sienkiewicza, dotyczących jednak głównie Notatek z podróży do Ameryki, zob. też A. Budrewicz-Beratan, American Travel Books of Charles Dickens and Henryk Sienkiewicz. W zb.: Metamorphoses of Travel Writing: Across Theories, Genres. Centuries and Literary Tradition. Ed. G. M o r o z, J. Szt a c h els k a. Newcastle upon Tyne 2010.

31 Tomasik, op. cit., s. 52.

32 Zob. więcej na temat Urania Cottage na stronie: http://victorianweb.org/authors/dickens/rogers/1. html (data dostępu: 5 II 2018).

33 Kamińs ki, op. cit., s. 210-211.

34 Ibidem, s. 212. 
Czy istotne jest zresztą, skąd Sienkiewicz zaczerpnął swój pomysł? Ważniejsze wydaje się bowiem samo szukanie przez niego remedium na występki wynikające z biedy w dobrze zorganizowanej świeckiej działalności dobroczynnej, umożliwiającej poprawę moralną jednostek. Nadmieńmy, że takie idealizujące ujęcie nie ma nic wspólnego $\mathrm{z}$ realnie panującym w tym czasie w Anglii systemem pracy przymusowej, której - jak to przedstawiał chociażby Dickens w Oliwerze Twiście - poddawani byli pensjonariusze przytułków ${ }^{35}$. Podkreślmy też, że opis skutecznej dobroczynności, rozwijanej dzięki stabilnym strukturom polityczno-społecznym oraz poczuciu obowiązku i solidności (jak z ironią stwierdza Sienkiewicz: „Dziwni ludzie ci Anglicy. Wyobraźcie sobie, moi mili współobywatele, że członkowie licznych tutejszych towarzystw nie zalegają nigdy w opłacie składki! Słyszeliście o czymś podobnym?” 〈S 47〉), jest pisarzowi potrzebny dla przeciwstawienia jej polskim filantropom, których dobre intencje rozpływają się w morzu wielosłowia rozmaitych komitetów, a miłosierdzie stanowi przykrywkę dla działań motywowanych pobudkami egoistycznymi. Tak więc przodująca na polu ekonomii, techniki i dynamizmu rozwojowego, jednocześnie zaś w sposób mądry konserwatywna, wiktoriańska Anglia (zostało tu użyte oksymoroniczne sformułowanie: „postęp [...] przybrany w średniowieczny kostium [...]” 〈S 31〉) zyskuje w Listach swoje polskie - a ściślej mówiąc - warszawskie odbicie w krzywym zwierciadle.

$\mathrm{Na}$ koniec tej części artykułu powróce do historii Jenny uratowanej przed demoralizacja - po to, by przywołać kolejny kontekst, tym razem jednak taki, który mógłby podważyć jednoznaczność moralistyczno-filantropijnego dyskursu Litwosa. Otóż jego ulukrowany obrazek ujawnia małe pęknięcie, łatwą do przeoczenia aluzję. Lekarz przychodzący do dziewczyny zwraca się do niej imieniem „Fanny”, które ona poprawia na „Jenny”. Cała ta niejasna na poziomie logiki opowieści omyłka tłumaczyć się daje w innym porządku: odwołania do tekstu sytuowanego na antypodach moralistyki. Fanny to bowiem imię bohaterki jednej $z$ najsłynniejszych erotycznych powieści wszechczasów, wydanych po raz pierwszy w 1748 roku Pamiętników Fanny Hill. Książka autorstwa Johna Clelanda ukazuje londyńska prostytutkę, której losy pozornie moglibyśmy uznać za modelowe również dla sentymentalnych fabuł XIX-wiecznych. Oto dziewczyna nie ze swej winy popada w grzech (jej rodzina umiera podczas zarazy, ona zaś, bez środków do życia, okazuje się łatwym łupem dla właścicielki domu publicznego), by w końcu wydobyć się $\mathrm{z}$ upodlenia i znaleźć szczęście w miłości. Wyzwaniem dla XIX-wiecznych literackich moralistów stało się jednak nie tylko bogactwo detali opisujacych realia „branży usług miłosnych”. Problemem jest też hedonizm bohaterki, przyświecające jej pragnienie „uprawiania miłości na najwyższym poziomie sztuki” 36 i czerpania $z$ tego zarówno przyjemności zmysłowej, jak i korzyści materialnych. Chodziło więc o to, że - jak nadmieniał jeden z krytyków powieści - Fanny nie tylko nie została ukarana pobytem w szpitalu czy więzieniu, ale udowodniła, iż opłaca się być niemoralną ${ }^{37}$.

Były to przedsięwzięcia realizowane na podstawie ustawy z roku 1834 (The Poor Law Amendment Act) znane jako poorhouses lub workhouses (zob. na stronie: http://www.victorianweb.org/history/ poorlaw/plintro.html 〈data dostępu: 5 II 2018〉).

37 Zob. A. Maksimiuk, S. Pazura, Prohibita. Setka ksiag zakazanych i pięćdziesiat powodów ku temu. Warszawa 1993, s. 46. 
Oczywiście, rodzi się pytanie, czy jest to świadoma aluzja, czy jedynie przypadkowa zbieżność imion. Moim zdaniem, choć jest to założenie wyłącznie poszlakowe, oparte na informacjach autorów badających popularność tego rodzaju tekstów w XIX i XX wieku, którzy podkreślali ich stosunkowo łatwą dostępność w Królestwie $^{38}$, nie był to przypadek. Utwór Clelanda znano tam zbyt dobrze, by przyjąc, że Sienkiewicz o nim nie słyszał ${ }^{39}$. Możemy ową aluzję odczytać jako rodzaj zakamuflowanego sygnału skierowanego do takich czytelników, którzy potrafili rozszyfrować nawiązanie przypominające o istnieniu porządków opowieści o kobiecie upadłej także innych niż moralistyczny. W ten sposób publicysta, nie przekraczając konwenansów obyczajowych, przywołał nurt skojarzeń erotycznych, których nie dało się wyrazić bezpośrednio. Wolno też uznać, że mamy tu do czynienia z symboliczna zmianą imienia bohaterki, ujawniającą różnicę między XVIII-wieczną, libertyńską Fanny a wyrzekającą się grzechu, wiktoriańską Jenny.

Niezależnie jednak od tej, wysoce prawdopodobnej, gry Litwosa $z$ tradycją literatury erotycznej trzeba podkreślić, iż w nurcie oficjalnym swojego publicystycznego dyskursu zaakceptował on angielski model społeczno-prawny jako - może nie bez pewnych wad, ale jednak optymalny w odniesieniu do realnej sytuacji kobiet ${ }^{40}$. Natomiast nie do przyjęcia w europejskich warunkach był dla pisarza emancypacyjny wzorzec amerykański, prowadzący zarówno do „niekobiecych” zachowań przedstawicielek „słabszej” płci, jak i do przedefiniowania ich miejsca w życiu publicznym.

Wizerunek Amerykanek w Listach jest im nieprzychylny i poddany zabiegom ośmieszającym, czego nie mogą zmienić żadne próby jego łagodzenia, stosowane w polskim dyskursie sienkiewiczowskim. Jedna $z$ badaczek określiła nawet obraz amerykańskich kobiet jako zabawny i przekorny wobec europejskiej mody na emancypację ${ }^{41}$. Ani bowiem ta moda nie została w Europie (nie mówiąc już o Polsce) powszechnie zaakceptowana, ani też dowcip Litwosa nie zawsze bywał tu najwyższych lotów, o czym świadczy choćby przywołany wcześniej passus dotyczący ka-

Zob. więcej na temat polskiego obiegu tekstów pornograficznych: A. Szwarc, Spory o granice pornografii - XIX i poczatek XX wieku. W zb.: Kobieta i rewolucja obyczajowa. Społeczno-kulturowe aspekty seksualności. Wiek XIX i XX. Zbiór studiów. Red. A. Ża rn ow s k a, A. Sz w a r c. Warszawa 2006. - M. C i e r e s z k o, Popularna pornografia? O rodzajach pornografii funkcjonujacych na ziemiach polskich na poczatku XX wieku i jej relacji z ówczesna kultura popularna. „Kultura i Historia” 2016, nr 29. Na stronie: http://www.kulturaihistoria.umcs.lublin.pl/archives/5720 (data dostępu: 10 II 2018).

Sienkiewicz mógł się zapoznać z którymś z wielu francuskich tłumaczeń lub przeróbek książki.

Trudno nie porównywać tej pozytywnej opinii opartej na kilku pobieżnych obserwacjach z założeniami opublikowanego zaledwie kilka lat wcześniej (w 1869 r.) przez J. S. Milla (Poddaństwo kobiet. W: O rzadzie reprezentatywnym. - Poddaństwo kobiet. Przekład przejrzał, wstępem opatrzył J. Hołówka. Przeł. G. Czernicki, M. Chyżyńska. Kraków 1995) słynnego sufrażystowskiego manifestu, w którym sytuacja Angielek zostaje określona mianem „legalnego niewolnictwa”, (s. 363). Możemy tam też przeczytać o niesprawiedliwości angielskiego prawodawstwa, nie pozwalającego kobiecie na dysponowanie swoim majątkiem, nie gwarantującego jej ochrony przed przemocą domową, a nawet pozbawiającego praw do opieki nad dziećmi w razie rozstania się Z mężem.

41 Zob. H. P a r a fi a n ow i c z, Ameryka i Amerykanie w świetle „Listów z podróży” Henryka Sienkiewicza. „Studia Podlaskie” 2003, s. 19. 
lifornijskiego prawa o karaniu przemocy domowej. Wypadałoby jedynie zgodzić się z tym, że był to dyskurs opozycyjny wobec nurtu wypowiedzi ujawniających podziw dla amerykańskiej praktyki emancypacyjnej, niekiedy nawet robiący wrażenie bezpośredniej polemiki $\mathrm{z}$ zawartymi $\mathrm{w}$ tych wypowiedziach tezami. Rozważania pisarza na temat amerykańskich kobiet należałoby więc czytać w kontekście prac opublikowanych w latach poprzedzających jego wyprawę, m.in. tłumaczeń dzieła Célestina Hippeau Wychowanie publiczne $w$ Stanach Zjednoczonych Ameryki Pótnocnej (1873) oraz Olimpii Audouard Podróż po Ameryce Pótnocnej (1872), a także głośnej książki Edwarda Prądzyńskiego O prawach kobiety (1873). Przyjmując też, jak czyni to część sienkiewiczologów, że Litwos znał w tym czasie traktat Alexisa de Tocqueville' ${ }^{42}$, winniśmy zwrócić również uwagę na istotne różnice w sposobie opisywania mieszkanek Stanów przez obu autorów.

Zanim jednak odniosę się do tego polemicznego wydźwięku dyskursu Sienkiewicza, przypomne jego, utrwalane w kolejnych korespondencjach, spotkania z Amerykankami. Już pierwsze z nich, odzwierciedlone w liście „oceanicznym”, możemy uznać za zdecydowanie nieudane. Niechęć wobec prostactwa obyczajów oraz cech charakteru mieszkańców Stanów Zjednoczonych przekłada się na karykaturalność opisów. Nieliczne neutralne wzmianki (obraz młodej amerykańskiej pary) nie równoważą tego, ogólnie złego, osądu Jankesów. Oto bowiem prezentuje Litwos „gwiazdę, Miss N.”, która jej ziomkowie chwala jako ,jedną z najznakomitszych artystek na świecie” (S 72). Owa pianistka, fałszująca Szopena tak, że „polskie uszy literalnie więdną [...]”, to pierwsza z reprezentantek „anglosaksońskiej rasy”, o której dalej czytamy jako o pozbawionej muzycznych talentów (S 72), co zostaje przez publicystę potwierdzone z perspektywy dłuższego pobytu w Stanach: „Brak Amerykankom i pracy, i muzycznych zdolności, i wreszcie estetycznego poczucia” (S 210). $Z$ tym daleko idącym uogólnieniem, wyprowadzonym $z$ opinii krytycznej o jednym obejrzanym występie, łączy się kolejna sugestia Sienkiewicza, ujawniająca, przez zabieg ironii, amerykańską megalomanię:

Amerykanie byli [...] nadzwyczaj zadowoleni $z$ siebie i z swoich talentów. Pytali nas nawet $z$ pewną dumą: czy słyszeliśmy coś podobnego w Europie? - ja zaś odpowiadałem z całą szczerością, że istotnie nic podobnego w Europie nie słyszałem. [S 72-73]

Opisując cechy kobiet spotkanych w Nowym Świecie, autor Listów sugeruje negatywną ocenę nawet tam, gdzie pozornie mamy do czynienia jedynie $z$ informacją, jak to się dzieje we fragmencie nowojorskim:

Mnóstwo kobiet przychodzi bez mężczyzn, mnóstwo [...] nawet panien podróżuje bez żadnej opieki. Wszystkie stroją się tak, jak nigdzie w Europie, wszystkie przychodzą bez kapeluszów [...]. [S 79]

Wartościująca wymowa tej wypowiedzi wynika ze skontrastowania zachowań mieszkanek Nowego Jorku i Europejek. Niezależnie bowiem od ewoluującej w Listach oceny Amerykanów (mężczyzn), którzy przy bliższym poznaniu zyskują na wartości, w wypadku Amerykanek odwołanie do obyczajów starego kontynentu prawie zawsze je deprecjonuje. Kilkadziesiąt stronic dalej pojawia się kolejna uwaga, dokumen- 
tująca - przez wyliczenie kolorów sukien - papuzi gust mieszkanek amerykańskiej metropolii, które, jak pisze Sienkiewicz, choć pozbawione „rasy i dystynkcji”:

stroją się więcej jak wszystkie kobiety na świecie. Stojąc przez pół godziny na Broadway w New Yorku, więcej widziałem rozmaitych sukien jedwabnych i kaszmirowych, czarnych, żółtych, zielonych, pstrych i czerwonych, niżbym mógł zobaczyć na bulwarach w Paryżu. Niewiele w tym wszystkim smaku, ale wiele przepychu. W hotelach na obiady przychodziły damy postrojone jak na bal, w złotych manelach, zausznicach, naramiennikach itp. [S 103-104]

Wyraźnie pobrzmiewają w tym fragmencie utyskiwania Dickensa z jego Notatek z podróży do Ameryki, w których czytamy:

A jak ubrane są tutejsze kobiety! Przez dziesięć minut widziałem sukien rozmaitego koloru więcej, jak w innym miejscu można zobaczyć przez kilka dni! co za rozmaite parasolki! co za kolor na atłasach! co za wzory na cienkich pończochach! co za wąskie trzewiczki, jakie mnóstwo wstążek, kutasów i frenzli, jakie różnobarwne mantylki, w kraty, we wzory, w paski... Bóg wie jakie! ${ }^{43}$

Nie sam jednak brak gustu czy też skłonność do jaskrawych i bogatych strojów stają się tu podstawowym zarzutem publicysty. Znacznie groźniejsza wydaje się mu, wynikająca z „demokracji obyczajowej”, powszechność „związku zwanego "flirteszyn" (flirtation) [...]” (S 104), co prowadzić ma do swobody, o jakiej - idąc dalej za Litwosem - „nie możemy nawet mieć pojęcia” (S 210-211). Relacje damsko-męskie w Ameryce zostały też, jak to postrzega, zdominowane przez „nieznośny despotyzm kobiet”, które „Są nadzwyczajnie śmiałe, wyzywające i kokietki do tego stopnia, że słusznie można rzec, iż role tu zostały zmienione i strona prowokująca jest kobieta" (S 104). Okazuje się więc, że problem stanowi owa zamiana ról, której krytyka wyrasta z przekonania o naturalnej odmienności publicznych zachowań przedstawicieli obu płci. Wątpliwości Sienkiewicza budzą także, znacznie ostrzejsze niż w Europie, obyczajowe i prawne konsekwencje męskiej - by określić ją tu eufemistycznie - nieostrożności:

opinia [...] całą odpowiedzialność zwala na mężczyznę i wyłącznie jego tylko podaje na ohydę publiczną; a [...] prawodawstwo [...] pod karą ogromnych sum pieniężnych każe mu się żenić natychmiast i słuszność przyznaje kobiecie nawet wówczas, gdy widocznie rzeczy się mają inaczej. [S 212]

Tak więc jeśli ogólna ocena moralności amerykańskiej jest w ostatecznym rozrachunku pozytywna dzięki „demokratycznej oświacie, rozciągającej się na cały naród [...]” (S 194), o której gdzie indziej pisze Sienkiewicz, że zapewnia „towarzyską i obyczajową równość między ludźmi” (S 183), to konsekwencjom owej równości w odniesieniu do kobiet publicysta daje ocenę negatywną. Odnosi się ona tak do niewypełniania przypisanych im ról („Amerykanki [...] mniej sa pracowite [niż Europejki], mniej zajmują się domem, gospodarstwem domowym i kuchnią [...]", S 209), jak i do rozluźnienia obyczaju dopuszczającego, by młodzi ludzie obu płci widywali się „ze sobą sam na sam, ile razy im się podoba”, by chodzili „we dwoje na spacery”, słowem: byli „ciagle ze sobą [...]” (S 212). du niezwykłego nawet jak na XIX-wieczne normy tłumaczeń adaptacyjnych, m.in. ze względu na fonetyczny zapis angielskich nazw własnych: K. Dikkins (Ch. Dickens), Zarysy Ameryki. Warszawa 1844, s. 71. Na stronie: https://polona.pl/item/zarysy-ameryki,OTAxMjIzNzg/\#info: metadata (data dostępu: 5 IV 2019). 
W konsekwencji - jak mniema korespondent - kobiety amerykańskie $\mathrm{z}$ wyższych i średnich sfer stają się grupą uprzywilejowaną. O ile ich mężowie zarabiają w pocie czoła na swe rodziny, o tyle one:

Po całych dniach siedzą na biegunowych krzesłach, kołysząc się pokazują nóżki, szczerzą ząbki, gwarzą, śmieją się, kokietują w nader elementarny sposób - zresztą nie robią nic. [...]

[...] Żyją tylko życiem zewnętrznym - brak im częstokroć inteligencji, serca i umysłu, skupienia, refleksji - słowem, sa to wesołe kozy ${ }^{44}$.

Wzmocniony deminutywami stereotypowy opis odwołuje się do założenia o niedojrzałości społecznej Amerykanek. Ta diagnoza, gdzie indziej zresztą wyrażona wprost: „Może dlatego kobieta jest tu po trochu zepsutym dzieckiem” (S 206), ma ujawnić ich specyficzny status. Przedstawicielke „słabszej” płci „Prawodawstwo [...] kokietuje, obyczaj daje jej wolność, opinia osłania nawet wtedy, kiedy broi, mężczyzna ją rozpieszcza” (S 206). Równocześnie wykorzystuje też publicysta język handlowy („popyt tu na płeć piękną daleko jest większy od podaży”, S 105), korespondujacy z całym - niejednokrotnie opisywanym w Listach - zracjonalizowanym i biznesowym sposobem kształtowania relacji międzyludzkich w Ameryce. Jest to ocena odmienna od tej, którą możemy wyczytać u Tocqueville’a, zupełnie inaczej niż Sienkiewicz postrzegającego konsekwencje większej swobody mieszkanek Stanów Zjednoczonych w rozporządzaniu własnym losem:

Rzadkością jest, by Amerykanka, niezależnie od swego wieku, okazywała dziecinną nieśmiałość i nieświadomość. Pragnie się podobać tak samo jak młoda dziewczyna w Europie, ale dokładnie wie, za jaką cenę. Choć nie oddaje się złu, to na pewno jest świadoma jego istnienia, i raczej może powiedzieć, że ma czyste obyczaje niż niewinny umys ${ }^{45}$.

Choć więc ogólne poglądy autorów francuskiego i polskiego na temat odmienności ról społecznych przypisanych obu płciom nie były zapewne nazbyt rozbieżne (obaj upatrywali tę odmienność w różnicach fizycznych, psychicznych i moralnych), to jednak sposób wypełniania swej roli przez Amerykanki pierwszy z nich postrzegał w świetle o wiele bardziej pozytywnym. Czytamy np. w jego dziele o „młodych amerykańskich mężatkach”, które poddają się „bez skargi surowym obowiązkom nowej kondycji” 46 .

Sienkiewicz z satysfakcją rozwiewa również rozpowszechniane w Polsce amerykańskie mity emancypacyjne, które - jak ujmuje to w specyficznym dla siebie sarkastycznym tonie - „co krok napotykamy u nas w książkach poświęconych sprawie kobiecej i w ulotnych artykulikach dziennikarskich i broszurowych zatytułowanych: Słówko w sprawie kobiecej, Kilka słów, Jeszcze słówko albo w rozmaitych Ziarnkach społecznych, których, mówiąc nawiasem, nikt dziobać nie chce" (S 203).

Publicysta nie atakuje samych ideowych założeń emancypacji, co zapewne nazbyt kłóciłoby się $\mathrm{z}$ jego pochwałą amerykańskich swobód demokratycznych,

H. Si en ki ew i z z, Listy z podróży do Ameryki. T. 2. W: Dzieła, t. 42, s. 234.

De Tocqueville, op. cit., s. 567.

Ibidem, s. 570. Pamiętajmy jednak również o różnicach spojrzenia wynikających z odstępu czasowego między obiema podróżami do Ameryki. Dzieli je prawie pół wieku polityczno-społecznych przemian w tym kraju, m.in. będących konsekwencją kilkuletniej wojny domowej. 
a głównie deprecjonuje skuteczność jej oddziaływania na realne życie społeczne. Jak czytamy:

Amerykanie maja jeden nieoszacowany przymiot, to jest: odwagę próbowania wszystkiego, co tylko przedstawia się jako teoria dążąca do ulepszeń życia ludzkości i postępu. Jeśli tylko taka teoria nie jest oczywistym, bijącym w oczy głupstwem, jeśli znajduje swoich stronników, wyradza naukowe spory, ma za soba jakiekolwiek dane, wówczas otwierają jej nareszcie wrota do praktyki. [...]

[...] Ruch więc rozpoczął się swobodnie i ogarnął umysły. Poczęły wzbierać fale, góra jęczeć - i urodziła się... mysz.

Jednym słowem, emancypacja w takim znaczeniu, w jakim ją określiłem, nie weszła w życie. [S 200-201]

Eksponuje się tu głównie niedojrzałość kobiet nie umiejących właściwie wykorzystać swoich praw. Jeśli więc Prądzyński wskazywał na praktykę zatrudniania Amerykanek w przemyśle i usługach („Wolność pracy jest tam dla niej prawie nieograniczoną, wstęp do wszystkich zawodów otwartym" ${ }^{47}$ ), to Sienkiewicz dowodził, że „w pracach i obowiąkach społecznych kobieta niewielki tu bierze udział” (S 202). Jeśli Prądzyński pisał, że „kobieta tym lepiej zrozumie i wypełni wszystkie, a zatem i najważniejsze rodzinne swoje powinności, im więcej rozwinie wykształceniem swoją osobistość [...]"48, to, zdaniem autora Listów, nadmiar edukacji nie tylko nie jest kobiecie potrzebny, ale nawet naraża ją na wyśmianie przez opinię publiczną (S 201). Dalej też, jeśli w pracy Olympe Audouard można odnaleźć następującą informację:

We wszystkich szkołach, we wszystkich uniwersytetach, kursach dodatkowych, kursach wyższych, w szkołach normalnych mieszanych, płeć żeńska, podług zeznania profesorów i dyrektorów, pod żadnym względem nie stoi niżej od męskiej, w jakiejkolwiek gałęzi wiadomości ludzkich ${ }^{49}$.

- to Litwos ripostuje ze znaczną dozą złośliwości: „nic nie stoi na przeszkodzie przyjmowaniu kobiet na fakultety prawne, medyczne; ale swoją drogą bardzo ich mała ilość z tych praw korzysta” (S 203), skoro „bujać się na krześle z biegunami, a inaczej mówiąc: żyć wesoło i bez troski, przyjemniej jest, niż wytężać umysł lub muskuły" (S 205-206). Jeśli czytamy u Audouard o kobietach: profesorach, agentach bankowych, a także o jednej tylko - co prawda - przedstawicielce płci żeńskiej, będącej kapitanem ${ }^{50}$, to polski publicysta nawet w studentkach widzi „wyjątki, po największej części indywidua obdarzone przy tym chorobliwą fantazją, za którymi ogół kobiet wcale nie idzie [...]" (S 201).

I tu właśnie pojawia się ostateczny argument Sienkiewicza przeciwko emancypacji zawodowej kobiet:

Proszę bowiem: co byście powiedzieli o kobiecie-duchownym, która by spowiadała swego męża? albo jeszcze więcej: o żeńskim pułkowniku? A gdyby tak w razie wojny takiemu pułkownikowi przyszło nagle prosić nieprzyjaciół o zawieszenie broni z powodu spodziewanego powiększenia się o jedną niepolona.pl/item/o-prawach-kobiety,ODg2MTgwOTc/193/\#info:metadata (data dostępu: 5 IV 2019). Ibidem, s. 213.

49 O. A u d o u a r d, Podróż po Ameryce Pótnocnej. Warszawa 1872, s. 143. Na stronie: https://polona. $\mathrm{pl} /$ item/podroz-po-ameryce-polnocnej,MTE4OTUwNQ/2/\#info:metadata (data dostępu: 5 IV 2019). 
winną istotę sztabu? Takie kłopotliwe położenie wodzów wpłynęłoby może skuteczniej na złagodzenie okropności wojny niż konferencje brukselskie. Chociaż nie! Świadomi rzeczy mówią, że widok tego wydającego sopranem rozkazy pułkownika i jego plastyczne kształty równie plastycznie rysujące się w obcisłym ubiorze żołnierskim dziwnie dodatnio wpływają na zapał żołnierzy. [S 201]

Odwołanie się do porządku fizjologicznego, jakoby udaremniającego pełne uczestnictwo kobiet w życiu publicznym i negującego możliwość poważnego ich traktowania przez mężczyzn, musiało nasuwać się jako oczywiste, skoro odnajdujemy je po kilkunastu latach w podobnej formie (choć już bez aluzji erotycznych), w osławionej ze względu na gorliwą obronę tradycyjnie postrzeganej wyższości mężczyzny, antyemancypacyjnej broszurze księdza Karola Niedziałkowskiego, w której ów argument przybrał kształt następujący:

Jest bardzo roztropne pomijanie milczeniem dość ważnej jednak kwestyi, czy i służba wojskowa ma być objęta równouprawnieniem - kto ma zastępować matkę, gdy będzie obradowała w sejmie, spełniała funkcyje gubernatora prowincyi lub ślęczała w pracowni nad retortami - a także, kto będzie spełniał za nią te obowiązki w pewnych dość długich okresach, w których żony, matki i karmicielki nie nadają się do obowiązków gubernatora, adwokata, prezydenta i generała? ${ }^{51}$

Na takim negatywnym tle niekonsekwencją autora Listów wydaje się jego aprobatywny stosunek do przypisanego kobietom zawodu nauczycielskiego. Jeśli bowiem w ogólnym obrazie mieszkanek Stanów Zjednoczonych bardzo mało jest cech ocenianych pozytywnie, to odwołanie do kobiet jako „Z natury bardziej idealnych [...]” (S 99), pojawia się dopiero w odniesieniu do ich misji edukacyjnej ${ }^{52}$. Jak jednak wiadomo, argument o moralnej wyższości płci „słabszej” bywał w dyskursie emancypacyjnym dwuznaczny, gdyż stawał się narzędziem jej ograniczania do ról społeczno-kulturowych uznanych za nie sprzeniewierzające się owej moralności ${ }^{53}$. Winniśmy też pamiętać o postrzeganiu przez Litwosa tej profesji kobiet tylko jako przejściowej w drodze do małżeństwa, co ujawnia po literacku zaaranżowana scenka obrazująca w humorystycznym zagęszczeniu cechy romantycznej wyobraźni kobiecej:

Oto każda nauczycielka jest to po największej części interesting young lady, w której samotność rozwija do wysokiego stopnia usposobienie romansowe, młodość zaś i krew gwałtu krzyczy na pustyni. Skutkiem tego zdarza się najczęściej, że jaki młody rycerz pustyni, jaki traper lub farmer, ubrany przez panieńską wyobraźnię w tęczowe kolory bohaterstwa, wsiąka w tę wyobraźnię jak potoki dżdżu w ziemię, a potem następuja „widywania się pod jaworu drzewem”, potem ciche ,jam twój - ty moja - tyś mój” i inne zaimki dzierżawcze odmieniane przez wszystkie przypadki [...]. [S 103]

W kontekście problematyki kobiecej warto też zwrócić uwagę na list do Daniela Zglińskiego, w którym bardzo silnie wybrzmiewa postawa lekceważenia i niechę-

K. N i e d zi a ł k o w s ki, Nie tędy droga, Szanowne Panie! (Studium o emancypacji kobiet). Warszawa 1897, s. 47. Na stronie: https://polona.pl/item/nie-tedy-droga-szanowne-panie-studyum-o-e mancypacyi-kobiet,ODk3NTU2OTc/\#info:metadata (data dostępu: 5 IV 2019).

52 Za dobrą monetę przyjął tę deklarację $\mathrm{Naj}$ d e r (op. cit., s. 89) i uogólnił ją na cały utwór w zdaniu, iż Sienkiewicz „niepomiernie idealizował kobiety amerykańskie [...]”.

53 Jak pisał A. W iśli c ki (Niezależność kobiety. „Przegląd Tygodniowy” 1866, nr 8, s. 3. Na stronie: https://polona.pl/item/przeglad-tygodniowy-zycia-spolecznego-literatury-i-sztuki-r-1-nr-8-25lutego-1866,NDkyNjQ2Mzk/2/\#info:metadata 〈data dostępu: 5 IV 2019〉): „Oddając hołd, chętnie wskazujemy na bezczynność kobiety przez uczucie serca, jako słabe fizyczne stworzenia”. 
ci do Amerykanek, ich uprzedmiotowienie także jako obiektów seksualnych w opisywanych bardzo bezpruderyjnie - jak na normy obyczajowe owych czasów - tego typu kontaktach ${ }^{54}$. Również szerszy kontekst prywatnej korespondencji pisarza dość wyraźnie ujawnia jego ambiwalentną ocenę kobiet, idealizowanie tych, które były mu bliskie, i skłonność do piętnowania negatywnych zachowań pozostałych napotykanych na swej drodze życiowej przedstawicielek płci pięknej. Widzimy to w młodzieńczych listach do Konrada Dobrskiego ${ }^{55}$, tak też dzieje się w późniejszej o 10 lat korespondencji Sienkiewicza z Julianem Horainem, w której doskonała w każdym calu Helena Modrzejewska zostaje przeciwstawiona reszcie kobiet $^{56}$. O stosunku pisarza do postulowanego zrównania praw edukacyjnych obu płci świadczy także jeden $\mathrm{z}$ jego listów do sióstr Szetkiewiczówien: Marii i Jadwigi, zarysowujący lekceważąco-złośliwy portret spotkanej w Wenecji „czerezwyczajno-progressiwnoj" (nadzwyczaj postępowej) Rosjanki, która:

Być może, [...] pisze w tej chwili jakieś studium $O$ żenszczinach rabotajuszczich na propriszczie sierioznoj nauki [...]. Na nieszczęście pod względem powierzchowności jest to skończony mandryl, albo co najmniej mogłaby być zaliczona do „wąskonosych” z okresu trzeciorzędowego, stanowiących, jak wiadomo, formę przechodnią do rodzaju homo sapiens ${ }^{57}$.

Podsumowując więc rozważania o Sienkiewiczowskim obrazie kobiet i kobiecości w Listach z podróży do Ameryki, pragnę podkreślić, że był w nich pisarz typowym dziecięciem (a właściwie mężczyzna) swych czasów, reprezentującym stereotypowe poglądy na temat różnic między płciami, utrwalone w dyskursie najbardziej prominentnych XIX-wiecznych myślicieli, od Heglowskiego założenia podziału ról życiowych według płci ${ }^{58}$, po Spencerowski darwinizm społeczny określający kobiece przeznaczenie jako aktywność w sferze rodzinnej ${ }^{59}$. Jak zresztą wskazywano, to właśnie w dyskusjach nad kwestią kobiecą radykalizm emancypacyjny najłatwiej ulegał wyciszeniu, prowadząc do zbliżenia stanowisk reprezentantów przeciwnych obozów ideowych ${ }^{60}$.

Sienkiewiczowski Grand Tour, który wymusił gwałtowne zanurzenie się pisarza

H. Sienkiewicz, Listy. T. 5, cz. 2. Oprac., wstęp, przypisy M. Bokszczanin. Warszawa 2009, s. 587-588.

H. Sienkiewicz, Listy. T. 1, cz. 1. Red., wstęp, biogramy adresatów J. Krzyżanowski. Oprac., przypisy M. Bokszczanin. Konsult. M. Korniłowicz. Warszawa 1977.

Ibidem, cz. 2.

57 H. Sienkiewicz, list do M. i J. Szetkiewiczówien. W: Listy. T. 2, cz. 1. Oprac. wstęp, przypisy M. Bokszczanin. Warszawa 1996, s. 120.

Pisał G. W. F. He gel (Zasady filozofii prawa. Przeł. A. La nd ma n. Warszawa 1969, s. 176) następująco o obu rolach: „mężczyzna ma swoje życie substancjalne w państwie, nauce itp. i w ogóle pracy, i walce ze światem zewnętrznym i ze sobą samym, tak iż tylko poprzez własne rozdwojenie może wywalczyć sobie swą samoistna jednię ze sobą samym; spokojne zaś oglądanie tej jedni i uczuciowa etyczność podmiotowa stają się jego udziałem w rodzinie, w której ż on a znajduje swe substancjalne przeznaczenie i której etyczną postawę stanowi miłość rodzinna".

59 Myśl ta pojawia się w najsłynniejszej pedagogicznej pracy H. S p en c e r a (O wychowaniu umy słowym, moralnymi fizycznym. Przeł. A. Pe retia tk ow i cz. Wstęp, koment. R. W roczy ń ski. Warszawa 2002, s. 219-221), skądinąd w sposób niezwykle światły opisującej założenia edukacji dzieci i młodzieży obu płci.

60 Zob. A. S zw a r c, Krytyka kobiecości czy próżniaczego stylu życia? Stare i nowe wzorce życia codziennego kobiet $w$ publicystyce i literaturze pięknej epoki pozytywizmu. W zb.: Kobieta $i$ kultura 
w świecie szybko postępującej modernizacji, jednocześnie wzmocnił jego obawy przed kierunkiem zmian wynikajacych z łagodzenia obyczajowego rygoryzmu kobiecych postaw i zachowań. Swoje poglądy Litwos ujawnił zarówno w angielskich obrazkach, w których doszła do głosu tęsknota za harmonią świata sprzed emancypacji, bronionego przez moc obyczajów, jak i w opisie amerykańskiego projektu emancypacyjnego jako przedsięwzięcia nieudanego. Publicysta nie atakował wprost jego założeń, ośmieszał natomiast sposoby realizacji, dowodził też braku zainteresowania nim ogółu kobiet. Dopowiedzmy, że nie było to w owym czasie myślenie odosobnione. Podobną opinię odnajdujemy u Bolesława Prusa, skądinąd przecież zwolennika zmian modernizacyjnych:

Dajcie powszechną oświatę, czasy spokojne, ogólny dobrobyt; niech praca męża wystarczy na utrzymanie żony i córek, a kobiety wyprą się emancypacji. Będą wolały stroić się, słuchać śpiewu słowika i wieńczyć poetów układających na ich cześć madrygały ${ }^{61}$.

Ujawniając, za pośrednictwem modelu amerykańskiego, demokratyzującego wszelkie stosunki międzyludzkie, „prawdziwą” naturę kobiet, o której czasem z pobłażliwością, niekiedy zaś z irytacją pisał jako o naturze dziecinnej, pozbawionej siły moralnej i zmysłu estetycznego, Sienkiewicz nie rezygnował z wyznaczania w ramach owego modelu optymalnych, bo uświęconych tradycją, terytoriów ich aktywności. Mam na myśli, po pierwsze, przestrzeń praktyczno-domową, w której „słabsza” płeć mogła być pomocnica mężczyzny (jak np. pozytywnie przedstawione ranczerki ${ }^{62}$ ), po drugie - aprobowaną niwę kobiecych działań, czyli edukację najmłodszego pokolenia, powiązana z łagodzeniem surowych obyczajów panujących na kolonizowanych terytoriach (jak w wypadku nauczycielek). Równocześnie perspektywa Nowego Świata, przynajmniej w tym jednym, emancypacyjnym aspekcie ujawniła Litwosowi wyższość europejskiej tradycji nad amerykańskim postępem. Stąd aprobata dla angielskiego, paternalistycznego modelu społecznego, w którego ramach dość ograniczone wolności kobiet były gwarantowane opiekuńczością mężczyzn, nie łączyły się zatem z prawnym kwestionowaniem nadrzędności ich pozycji społecznej.

\author{
Abstract \\ ALEKSANDRA CHOMIUK Maria Curie-Skłodowska University, Lublin \\ ORCID: 0000-0002-3236-615X
}

\title{
THE IMAGE OF WOMAN IN HENRYK SIENKIEWICZ'S AMERICAN CORRESPONDENCE
}

The article presents Sienkiewicz's images of women from his Listy z podróży do Ameryki (Letters from a Trip to America). It researches Litwos' statements referring to real and postulated woman behaviours, the social roles attributed to women, and the features which constitute femininity as a social-cultural category. The discourses concerning the differences between sexes and emancipation problems contemporary to Sienkiewicz make a broader context of the presented journalistic observations.

życia codziennego. Wiek XIX i XX. Zbiór studiów. Red. A. Żarnowska, A. Szwarc. Warszawa 1997, s. 306.

61 B. Prus, Kronika tygodniowa. „Kurier Warszawski” 1879, nr 268, z 17 (29) XI, s. 3. Cyt. za: Szw a r c, Krytyka kobiecości, s. 304.

62 Sienki ew i c z, Listy z podróży do Ameryki, t. 2, s. 235. 